\title{
Merre tovább szociális munka?
}

az online konferencia szerkesztett változata

Az ELTE TáTK Szociális Munka Tanszék panelbeszélgetést szervezett hat ország képviselőivel 2020. június 11-én arról, hogy a COVID-19 hatására a szociális munka területén milyen változások történtek.

A panelbeszélgetés résztvevői:

- Ronald Woods (University of Technology Sydney, Ausztrália)

- Katz Katalin (Hebrew University of Jerusalem, Izrael)

- Støren-Váczy Blanka (Oslo Metropolitan University, Norvégia)

- Filesch Zsuzsanna (Katholische Stiftungshochschule München, Németország)

- Temesváry Zsolt (University of Applied Sciences and Arts Northwestern Switzerland)

- Szoboszlai Katalin (Debreceni Egyetem Egészségügyi Kar, Magyarország)

A beszélgetést Hegyesi Gábor és Rácz Andrea, az ELTE TáTK Szociális Munka Tanszék oktatói moderálták.

Rácz Andrea: Az ihlette ezt a mai találkozót, hogy fontos lenne egy olyan beszélgetés, amiben a szociális munka kihívásait vennénk sorra azokkal a nemzetközi és hazai partnerekkel, akikkel régóta dolgozunk együtt és jelenleg is vannak közös együttmüködéseink. Fontos lenne ránézni, hogy a járványügyi helyzetben mi történt a szociális munka képzésben, a szociális munka praxisában milyen új megoldásokat, kihívásokat, útkereséseket hozott a járvány, és a különböző országok gyakorlatából mit tudunk tanulni. Két körkérdéskör mentén beszélgetünk: 1) a képzés tapasztalatai és 2) a praxisban történt változások.

Hegyesi Gábor: A szociális munka képzés 30 éves az idén az ELTE-n és több képzőhely is ünnepel ebben az évben. 1985-ben indult Ferge Zsuzsa vezetésével a szociálpolitika képzés is. Az induláskor sok segítséget kaptunk külföldről, Izraelből, Németországból, a skandináv országokból, Svájcból, persze az USA-ból is, így nagyon fontosak azok a tapasztalatok, amiket most is megosztanak velünk a vendégeink, hiszen az induláskor is jelen voltak sokan személyükben is, mint Ronald Woods.

Milyen változásokat hozott a vírus a szociális munka képzésben? Kérnénk, hogy a kontextusra is röviden térjetek ki. Ausztráliából indulunk, és így érkezünk meg Magyarországra.

Ronald Woods: Ausztrália sikeresen kezeli a vírust, mert az országnak nagyon fontos az egészségügy. Az országnak 25 millió lakosa van, ebből 7283 a fertőzött, meggyógyult 6774 és 
meghalt 102 fö. A legnagyobb fertőzési forrást a luxushajók jelentették. Azt, hogy milyen kihívásokat hozott a képzésben a járvány, három kategóriában vizsgálnám: praktikusan, szakmai tudásban és az oktatásban. Praktikusan gyorsan bezárták az egyetemeket, és távoktatási módszereket kellett rövid időn belül bevezetni. A szakmai tudás terén a tanároknak gyorsan kellett tanulniuk, hogy mi is ez a koronavírus és a járvány milyen befolyással van az ember és környezet közti kapcsolatra. Az oktatásban a legnagyobb szakmai kérdést az jelentette, hogy hogyan lehet terepgyakorlatot végezni.

Katz Katalin: Izrael egészségügyileg nagyon jól vizsgázott az elmúlt időszakig. Mindent nagyon gyorsan lezártak (határokat, boltokat, intézményeket). 18300 fő a regisztrált betegek száma, 300-an vesztették életüket, 15200 fö meggyógyult és április végére már nem volt megbetegedés. Május végén megnyitották az iskolákat, üzleteket, ennek következtében minden fegyelem felborult és június 10-én 180 új beteg lett. A márciusi bezáráskor 140 volt a napi betegek száma. Fontos megjegyezni, hogy a nem koronavírusos betegeket továbbra is ellátták. Csak az úgynevezett nélkülözhetetlen titulust kapott dolgozók hagyhatták el otthonaikat, köztük a szociális munkások is, akik tartották a kapcsolatot a kliensekkel. A vírus elött 4\% volt, most 24\% a munkanélküliség. Az egyetemek bezártak, a tanítás online formában folytatódik, az órák az eredeti órarend szerint mennek tovább, az oktatók gyorsan és jól alkalmazkodtak az új helyzethez. A gyakorlati oktatás szemben az említett ausztrál gyakorlattal ment tovább, mint rendesen, mert ezek az intézmények nem zártak be. A képzés sajátossága, hogy 1. évtől kezdve a terepen dolgoznak a diákok.

Støren-Váczy Blanka: Norvégiában március 12-én bezártak mindent tulajdonképpen, egyik óráról a másikra, ami azt jelentette, hogy bezárták az iskolákat, egyetemeket, az összes kulturális és sportlétesítményeket, tréning stúdiókat és a home office kötelezővé vált, szinte mindenhol. A boltok nem zártak be és időkorlátozás sem volt. A kormány szigorú intézkedései kihatottak a gazdaságra és a foglalkoztatásra, melyet az is tükrözött, hogy olyan magas lett munkanélküliség, amilyen még nem volt 1932 óta. Ami az egyetemi képzést illeti, azt lehet mondani, hogy egy hét alatt kellett áttérni a digitális oktatásra, az előadókra volt bízva, hogy ezt hogyan oldják meg. A digitális pedagógiai megoldások, a digitális eszközök használata az oktatásban már korábban elkezdődtek az egyetemen, ennek egyik oka az is, hogy egy külön „digitális” iroda jött létre kb. két éve, ami kimondottan a képzések digitalizációját segíti. Ami a szociális munkás képzésünket illeti, a legnagyobb kihívást Norvégiában is a szakmai gyakorlat jelentette. Az 1. éves hallgatóknak egy 12 hetes intenzív gyakorlat van a tavaszi szemeszterben, de ezt sajnos nem mindenki tudta befejezni. A gyakorlatnak nagy jelentősége van, hiszen az alkalmasságot is vizsgálja, ez egyfajta szürö. A gyakorlat teljes letöltése fontos, mert aki nem fejezi be a terepgyakorlatot az első évben, az nem mehet tovább. Most azon dolgoznak a kollégák, hogy a lemaradók szeptemberben tudjanak pótolni. A másik nagy kihívást egy kommunikációs és tanácsadói készségfejlesztő szeminárium részbeni elmaradása jelentette. A szeminárium kis csoportokban valósul meg és elengedhetetlen a személyes jelenlét. Ezt részben digitalizálni kellett, hogy az évet le tudja zárni a hallgató, de mivel a harmadév egy 12 hetes gyakorlattal kezdődik, ahol már önállóan dolgozhatnak ügyfelekkel, kliensekkel, ezért ez a szeminárium elengedhetetlen. Most a gyakorlat mellé a harmadévben külön kommunikációs és tanácsadói készségfejlesztő szemináriumot illesztettünk be. 
Filesch Zsuzsanna: Németországban 188 ezer megbetegedés volt, 170 ezren gyógyultak meg, 8800-an vesztették az életüket a Covid-19 következtében. A járvány kitörésekor az élelmiszerboltok, kórházak, tüzoltóság, rendőrség, katonaság kivételével mindent bezártak. A német lakosság szigorúan betartotta a politikai szervezetek által hozott szabályokat. Az egészségügy nagyon jól oldotta meg a fellépő problémákat. A munkanélküliség nem emelkedett drasztikusan, a hat százalék 2\%- kal nőtt meg. Akik nem tudtak otthonról dolgozni (home office-ban), azok a személyek, úgynevezett „Kurzarbeit” lehetőséggel otthon maradtak, de kapták fizetésük 65-85\%-át.

Minden oktatási intézményt bezártak. A felsőoktatás azonban igen gyorsan átállt a digitális tanításra, ami nem jelentett kihívást Németországban, mert ez a jellegü technika pár éve gyakorlatban volt „e-learnig” néven. Hallgatóink megváltozott élethelyzete sokakban bizonytalanságot és ebből adódóan labilis pszichikai állapotot váltott ki. A szociális munkás stúdium az oktatók jelenlétét kívánja sok esetben, a személyes kapcsolat hiánya a szakmai képzést gyengíti. Mi arra törekedtünk, törekszünk, hogy ezt a félévet a hallgatóink sikeresen zárják le. Az írásbeli munka sajnos megnövekedett, de a Zoom lehetővé teszi, hogy egy kis „személyes találkozás” könnyítse a félév sikeres lezárását.

Temesváry Zsolt: Svájcban 30 ezer megbetegedés volt, 1700 halálos áldozat, Basel kantonban 3000 megbetegedés és 50 elhalálozás, ebből 30 fö idősek otthonában lakott. Viszonylag enyhék voltak a korlátozások, kijárási tilalom nem volt, de volt határzár, és kiemelendö, hogy a honvédség sokat segített a szociális területeken és a védekezésben is. A mobil szüröállomások hamar felálltak a tesztelésre. Gazdasági területen nagy visszaesés nincs, a munkanélküliség 2,5\%-ról 3,4\%-ra nőtt, bár a kifutás későbbre várható. A rövidített munkarend itt is bevezetésre került, akárcsak Németországban, a munkavállalók 38\%-át érintette, akik fizetést kaptak, de nem tudtak home office-ban dolgozni. Bezártak az egyetemek, gyorsan átálltak az oktatók a digitális oktatásra, amihez a felkészültség többnyire adott volt. A frontális módszerek egyértelműen nem működnek az online térben, de a kiscsoportos formák, új megoldások igen, ebbe viszont bele kell tanulniuk az oktatóknak. A szociális intézmények müködtek tovább, a hallgatók így az izraeli tapasztalatokhoz hasonlóan kint maradhattak a terepen. Ami viszont nagy veszteség a diákok oldaláról, hogy mivel nincsenek kollégiumok, kisebb lakóközösségekben élnek, több diák elvesztette a munkáját, így sokan nagyon nehéz szociális körülmények közé kerültek, vannak, akik, hazaköltöztek a szüleikhez, az egyetem próbálja most orvosolni pénzbeli támogatásokkal a nehéz helyzetüket.

Szoboszlai Katalin: Magyarországon az Operatív Törzs tájékoztatása alapján az elhunytak száma 553 fö, az aktív fertőzöttek száma 1095, a gyógyultak száma pedig 2391. Egy egészségügyi krízishelyzethez nagyon gyorsan egy gazdasági és egy szociális krízishelyzet társult, miközben a minőségi tájékoztatás elmaradt. Rövid időn belül kellett áttérni a digitális oktatásra, az egyetemek digitális oktatáshoz szükséges informatikai támogatottsága nagyon alacsony, ezért az ingyenes felületeket használják. A technikai felszereltség, Internet hiánya a diákok szempontjából is nagyon égető probléma. Az interaktív oktatás hiánya nagy probléma, a szociális munka oktatásában ez központi kérdés. Az online záróvizsga is kihívást jelent, mindenki próbálja a legjobb tudása szerint ezt megoldani. A szociális és gyermekvédelmi intézmények nagyon hamar elzárkóztak a gyakorlatoktól, így sok esetben a szakmai 
gyakorlatok teljesítése bizonytalanná vált. A szakmai gyakorlatot úgy igyekeztek megoldani, hogy elfogadtak például olyan megoldásokat, hogy idősek ellátásába való bekapcsolódás bevásárlással.

\section{Milyen változásokat hozott a vírus a szociális munka praxisában? Mit tanulhatunk mindebből? Mit tarthatunk meg? Magyarországról távolodunk ebben a körben Ausztrália felé.}

Szoboszlai Katalin: A járványhelyzetben védeni kell a klienseket is és magukat a szociális munkásokat is. Fontos volt megszervezni a megfelelő védőeszközök elérhetőségét, ami egyáltalán nem volt egyszerü feladat, nagy volt a kezdeti hiány. Hamar lezárták a hajléktalanszállókat, és aki nem ment be, kívül izolálódott. A hajléktalanoknak a szociális munkások voltak az egyedüli kontaktusaik, akiktől segítséget kaphattak, akik hozzájuk szóltak. Belülről kellett építkezni, kitalálni, hogy mit lehet tenni. Fontos megemlíteni, hogy a civil társadalom, az állampolgárok nagyon sokat segítettek, ami mindenképpen pozitívum, hiszen mindenki átérezte, hogy ez egy rendkívüli helyzet, és mindenki úgy érezte, hogy tennie kell valamit a saját eszközei, lehetőségei mentén. És hogy mit viszünk tovább? A szociális munka fejlődésébe a járványügyi helyzet tapasztalatai beépültek, tudjuk, hogy ha van egy vírushelyzet vagy akár kitágítva egy katasztrófahelyzet, mi az, amiben tudásunk van, mire vagyunk képesek és az is fontos tudás, hogy mire nem vagyunk képesek. A kormányzati kommunikáció és cselekvés késlekedett, de a szociális munkásoknak cselekedni kellett, hogy az elemi szükségletek biztosítottak legyenek. Új tudásokra van szükségünk, beleértve az egészségügy területéhez kapcsolódó szociális munkát vagy akár az informatikát, digitális eszközök használatát is, ez velünk marad, és ami jó ebböl, azt vinni kell tovább. Kutatásokra is szükségünk van, nagyon sok adat, információ született, sok új problémát érzékeltünk, ezeket jó lenne rendszerezni és ezekböl is közösen tanulni. Sok mindent láthatóbbá, élesebbé tett a járványhelyzet, mint például a szegények nélkülözése, a hajléktalanok helyzete. A szociális munka tárgyú kutatásokból kapunk olyan eredményeket, amelyeket a szociális munka fejlődésébe is be tudunk építeni.

Temesváry Zsolt: A svájci szociálpolitika rendkívül összetett, gyakorlatilag kantonális szinten különbözik maga az ellátórendszer és így a szociális munka gyakorlata is. Nagyon tagolt és heterogén a rendszer a 26 kantonnak megfelelően. A diákok többsége a diplomaszerzést követően az állami struktúrában helyezkedik el. Az idősellátás szinte kizárólag egyházi és magán kézben van, míg az állam biztosítja a családsegítést, segélyezést és tanácsadási területet. A civilek aktívak a hajléktalan ellátásban. Ök sokkal gyorsabban reagáltak a járvány idején a különböző speciális élethelyzetű emberek problémáira, mint pl. a prostituáltak vagy a hajléktalanok. A vírus megjelenésekor az állam viszont szinte teljesen blokkolt. Még élesebb lett a svájci állampolgárok és a kirekesztett csoportok között a szakadék. A papír nélkül Baselben élők, többnyire kelet-európai, bevándorló hátterüek nagyon nehéz helyzetben vannak amúgy is a járványtól függetlenül, nyilván az állam a jóléti turizmust akarja a szigorú intézkedésekkel megakadályozni. Míg pl. egy három csillagos szállodába kerültek a helyi 
hajléktalanok, a kelet-európaiak ide nem jutottak be, és sokkal alacsonyabb színvonalú ellátást kaptak. Bezártak a népkonyhák, így az élelmezésük is nehézségekbe ütközött. A gondozói munkát végző nők, de pl. a prostitúcióból élők is elveszették a munkájukat, a határzár miatt sokuk haza se tudott jutni, így hajléktalanná váltak, vagy teljes létbizonytalanságba sodródtak. A civilek erős hangja és aktivitása egy jelentős változást hozott, erősödni látszik a radikális szociális munka irányzata, egyre erősebb a kritikai szemlélet. A civilek rugalmassága is azt erősítette, hogy a szigorú esetmenedzseri, case work szemléletủ munka nem fog tudni továbbra megmaradni. Persze világosan látszik, hogy nagyon bürokratikus a jelenlegi rendszer, de mintha lenne döntéshozói elköteleződés a változás irányába. Egy pozitív irányú előrelépés, építkezés várható a szociális szektor egészében, pl. a bérek és munkakörülmények rendezése terén, mert láthatóvá vált a társadalomban a szociális munka jelentősége az egészségügyben dolgozók munkája mellett.

Filesch Zsuzsanna: Hasonlóan Svájchoz Németországban, és konkrétan Bajorországban gyorsan reagáltak a kirekesztett csoportok helyzetére. A hajléktalanok esetében, az idősek ellátásában, a rászorult családok segítésében, a gyermekek és fiatalok védelemben, a menekült otthonokban fellépö szükségesetekben azonnal kellett reagálni. Egy rövid sokkos, bénult idő után elindult a segítő gépezet. Poétikusan: a Korona krízis megtanított minket arra, hogy egyedül nem tudunk boldogulni! Németországban nagyon nagy hagyománya van az önkéntes, tiszteletbeli munkának, az úgynevezett önkéntes szociális munkának. A Covid-19 okozta szükséghelyzet nagyon sok embert ösztönzött erre a segítségre. A tevékenységük koordinálását természetesen a szociális munka vette a kezébe. Fontos tapasztalat volt, hogy a német szociális munka a digitális eszközök segítségével egy ilyen krízishelyzetben gyorsan tud involválni. Projekteket indítottak hallgatóink az oktatók irányításával, hogy hogyan lehet gyorsan és effektíven a segítségre szorulókat, bántalmazott gyermekeket, fiatalokat, érintett személyeket digitálisan elérni. Ehhez persze a klienseket digitális eszközökhöz kellett hozzá juttatni. Meg kellett az ehhez szükséges anyagi eszközöket találni.

Støren-Váczy Blanka: Azt a kérdést, hogy milyen kihívásokat hozott a vírus a szociális munka praxisában, két szemszögből lehet nézni: lehet a szociális munkás szemszögéböl, illetve a kliens szemszögéből. Az ügyfélnek pozitív változás jelentett, hogy a szociális ellátások időtartama meghosszabbodott Norvégiában, több idő maradt az ügyfelekre, szemben az adminisztráció túlsúlyával. A meeting-kultúrában elveszett ügyfél most elötérbe került. A szociális munkásoknak nem kellett megbeszélésre, képzésre, konferenciára járni. Az interdiszciplináris együttműködések is hatékonyabbá váltak, ahol együtt kellett dolgozni pl. orvossal, védőnővel, koncentráltabbá vált az ügy elörevitele. Norvégiában kevés a hajléktalanok száma, de pl. negatív hatással volt a lezárás azokra, akik foglalkozási rehabilitáció alatt állnak, nehezebben tudnak munkába állni, a segítői folyamat, ügyvitel, a nyílt munkaerőpiacra felkészítő képzések leálltak. A szociális munkás szemszögéből pozitív volt a digitális platformok tesztje, aminek a használata egy-két éve kezdődött, ezekben az esetekben nincsen személyes kapcsolat a szociális munkás és az ügyfél között. Azokban az esetekben, ahol megmaradt a személyes esetkezelés, ott több kihívással találkoztak a szociális munkások. A home office miatt a szociális munkások otthonról dolgoztak, és ez azt is jelentette, hogy az kliensek beláttak az esetkezelő privát szférájában és szó szerint az eseteket hazavitték, ami nehéz, konfliktusos esetekben kimerítő 
volt, mert egyedül maradtak az estekkel, mivel a gyors szupervízió - esetleg egy kollégától elmaradt. A másik kihívás maga a kommunikáció formája volt, ahol a szemtől szembeni személyes kommunikáció elmaradt és maradt a képernyő, ami egy másfajta kommunikációs alapot adott és kihatott a kapcsolat építésre, a kapcsolat formájára és mélységére, föleg az olyan esetekben, ahol a kliens új volt. Vagy olyan esetek során, ahol nagy szükség lett volna a személyes találkozásra, főleg krízisben lévő kliensek esetén. A kérdés az, hogy hogyan tudjuk a hallgatókat felkészíteni ezekre az új kihívásokra, amik a digitalizált ellátások elterjedésével jelennek meg és a kommunikáció új vagy eltérő formáját követelik meg.

Katz Katalin: Izraelben a jólléti állam hagyományai még megvannak, segíti a rászoruló embereket, ezért nagyon jó szociális tárgyú törvényeink vannak. A jelenlegi kormány ezt úgy játssza ki, hogy egyre több szolgáltatást privatizál. A privatizáció azt jelenti, hogy vagy privát kézbe kerülnek az ellátások vagy a civil szféra müködteti azokat, az állam csak felügyeleti jogot gyakorol. Meg kell azt is jegyezni, hogy a civil szervezetek nagyon nehéz helyzetbe kerültek a járvány hatására, beszűkültek a forrásaik, az állami támogatás, úgy, mint a külső adományok, majdnem teljesen leálltak. A járvány következményeként a fogyatékkal élő gyermekek például teljesen kimaradtak az ellátásból. A privát helyek teljesen bezártak vagy minimalizálták a szolgáltatásaikat. Az idősotthonokat bezárták, nem lehetett se bemenni, se kijönni. Az iskolák májusban ugyan megnyitottak, de a fogyatékos gyermekek mellől eltüntek a segítők, így nem tudnak iskolába járni. A járványügyi helyzetben nagy problémák merültek fel, mélyült a szegénység, nőtt az otthoni agresszió, a családon belüli erőszak. A szociális munkásokra maradt minden szociális probléma kezelése, tehát megsokszorozódott a feladatuk. Eddig is magasak voltak az esetszámok, de most például 1 szociális munkásra 300 család jut. Ami külön problémát jelent, hogy az agresszió a szociális munkásokra is irányul, amit valahogyan kezelni kellene. Hogy mit tanultunk? Elkezdődött egy nagy ellenállás a Szociális Munkások Uniója által, muszáj megküzdeni a szociális munka értékeiért a kormány ellenében. A szakmai érdekvédelemnek most nagyon fontos a szerepe.

Ronald Woods: Az időskori ellátás privatizált Ausztráliában, ez a terület a legnagyobb kihívás a szociális ellátásokon belül. Az egészségügyi szociális munka nagyon erős az országban, ha a COVID-19 pl. krónikus betegséggé válik, akkor az önsegítő csoportoknak fontos szerepe lesz, amiben a szociális munka nélkülözhetetlen. Még nem tudjuk, hogy ez a vírus mit hoz, hogy marad jelen. Nagy probléma az országban a munkanélküliség, az előrejelzések nagy gazdasági recessziót jeleznek. Az elszigetelődés a járványügyi helyzetben sok családi problémát, gyermekvédelmi helyzetet hozott a felszínre, gondoljunk csak a drog- és alkoholproblémára vagy a családon belüli bántalmazások növekvő számára. Fontos lesz a traumákat és a gyászt feldolgozni, mert sok ember elvesztette a járvány miatt a családtagját, nem tudott elbúcsúzni. Mindannyiunknak sok a vesztesége, fájdalom és gyász van az életünkben, mondhatjuk, hogy ez a poszt-COVID PTSD (poszttraumás COVID stressz), amiben vagyunk. A közösségi szerepvállalás egyre erőteljesebb és a közösségek építésében, a közösségi erőforrások mozgósításában a szociális munkának központi a szerepe történetileg is. 
Rácz Andrea: A beszélgetés nagy sikerére való tekintettel, tervezzük, hogy partnereinkkel folytatjuk a megkezdett munkát a tapasztalatok szélesebb és mélyebb megosztása érdekében egy-egy témát körbejárva, kitérve az új kutatásokra, a képzési és praxisbeli innovációkra, illetve az állam szerepvállalásának az átalakulására.

Szerkesztette: Rácz Andrea 